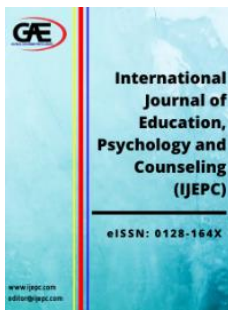

\section{INTERNATIONAL JOURNAL OF EDUCATION, PSYCHOLOGY AND COUNSELLING (IJEPC) \\ www.ijepc.com}

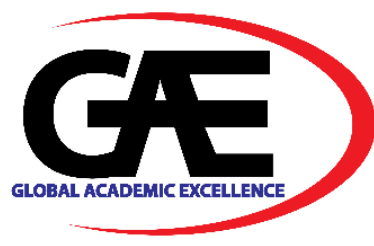

\title{
INFLUENCE OF ATTACHMENT STYLES ON ESTABLISHMENT OF ADOLESCENTS' IDENTITY AMONG SECONDARY SCHOOL STUDENTS FROM BLENDED FAMILIES IN KIAMBU COUNTY
}

\author{
Lucy Gachenia $^{1 *}$, Ruth Kamunyu ${ }^{2}$, Nathan Chiroma ${ }^{3}$ \\ 1 Department of Psychology, Pan Africa Christian University, Kenya \\ Email: lucy.gachenia@ pacuniversity.ac.ke \\ 2 Department of Psychology, Pan Africa Christian University, Kenya \\ Email: Ruth. Kamunyu @ pacuniversity.ac.ke \\ 3 Department of Children and Youth Ministry \\ Email: Nathan.Chiroma@pacuniversity.ac.ke \\ * Corresponding Author
}

\section{Article Info: \\ Article history: \\ Received date: 19.04 .2021 \\ Revised date: 30.04 .2021 \\ Accepted date: 10.12 .2021 \\ Published date: 15.12.2021 \\ To cite this document: \\ Gachenia, L., Kamunyu, R., \& Chiroma, N. (2021). Influence Of Attachment Styles On Establishment Of Adolescents' Identity Among Secondary School Students From Blended Families In Kiambu County. International Journal of Education, Psychology and Counseling, 6 (44), 137-154.}

DOI: 10.35631/IJEPC.644011

This work is licensed under $\underline{\mathrm{CC} B Y}$ 4.0 (c) 2

\section{Abstract:}

Parents adopt different attachment styles in parenting their children. This phenomenon is more profound in blended families where there are many relationships that can lead to many problems. However, with appropriate attachment styles adopted by step parents such challenges can be mitigated. The purpose of this study was to examine influence of attachment styles on establishment of adolescents' identity among secondary school students from blended family in Kiambu County, Kenya. Attachment theory by Bowlby guided this study. The study adopted a mixed method approach, descriptive causal effect design and pragmatic paradigm to guide the study. Multi-stage sampling method and inclusive /exclusive criteria were used. To begin with, the study adopted survey method as the sampling technique because the total population of adolescents that came from blended families was unknown. Simple random sampling was used to select 9 schools and also determine the 5 classes to be sampled in each of these schools. The 5 classes had a population of 55 students each. A short questionnaire with demographic data of students was issued to all the students (2475) in a bid to elicit the adolescents from the said classes that came from blended families in the 9 schools. A total number of 208 adolescents from blended families in the 9 schools was elicited and this was considered a sufficient sample size. In addition, simple random sampling was used to sample 24 respondents to form 4 focus groups while purposive sampling was used to sample 4 counsellors from 9 schools for in-depth interview. Data was collected using questionnaires, counsellors' interview schedule and focus group discussions. Inventory for Parent and Peer Attachment Scale and Identity Style Inventory were used as measuring tools. 


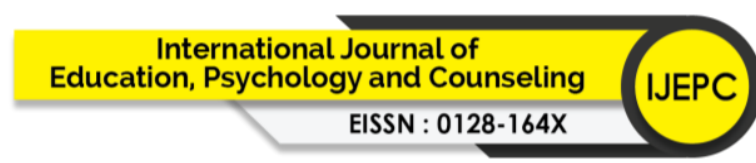

Volume 6 Issue 44 (December 2021) PP. 137-154

DOI 10.35631/IJEPC.644011

Data was analysed through descriptive statistics, statistical assumption tests, correlation tests- T- test, and MANCOVA analysis while qualitative data was analysed by use of narrative analysis. Findings were presented in form of tables while interview data was presented in narrative form. Permission to conduct the study was obtained from the National Council for Science and Technology, the Kiambu County Government, Ethical approval was sought from accredited IERC (Institutional Ethics Review Committee) as well as a written informed consent from the school administration. Results indicated that attachment styles adopted by step parents influence the establishment of adolescent informational, commitment and diffuse avoidant identity styles but not normative identity style. The study will benefit Ministry of Education, counsellors, parents, families and society.

Keywords:

Blended Families, Stepmother, Stepfather, Adolescents, Attachment Styles, Influence, Identity Styles

\section{Introduction}

Erickson (1993) theory stipulates that it is key for adolescents to develop self-congruency, identity stability and the need to establish a self-value system, for them to consolidate their identity growth. Further, a strong support system especially from parents or care givers is key for the identity process (Erickson, 1968). This brings to the fore the importance of parents presence in the lives of adolescents identity construction. Berzonsky (2004) on the other hand states that the end result of an individual's identity formation can either be strong or weak depending on their conflict resolution strategies and appropriate decision making process, and concurs with Erickson that parents are crucial in promoting adolescent identity by providing a conducive relational environment for them. This may imply that parent-adolescent relationship matters. The present study sought to explore adolescent identity formation from Berzonsky perspective to find out how attachment styles adopted by step parents affected adolescents identity styles development. The study discussed three components of identity styles namely; informational, normative and diffuse avoidant identity styles. Adolescents are focused in finding out who they are, their self- identity, explore individual values, beliefs and define their goals (Jensen et al., 2017). These aspects had not been fully explored especially from blended families' perspective hence the significance this study.

\section{Literature Review}

Adolescent identity development has been explained from three perspectives: Erickson (1968), Marcia (1980) and Berzonsky (1987). Erickon (1968) psychosocial growth has been viewed as a key development task of adolescence identity formation however, previous studies indicate that Erickson ideology lack support of empirical research methods. Marcia (1980) build on Erickson (1968) by extending Erickson model for adolescents and came up with a four identity status paradigm which comprises of diffusion, moratorium, fore closure and identity achievement but failed to look at identity formation as an outcome and failed to capture the core development process. To fill this gap Berzonsky (1987) came up with a social cognitive model of identity as an alternative model with the following components; informational, normative, and diffusion avoidant style. These explain the different ways in which adolescents' process, digest, explore, interpret and utilize identity significant information (Berzonsky, 1992). 


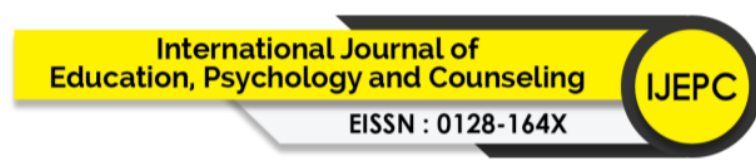

Volume 6 Issue 44 (December 2021) PP. 137-154

DOI 10.35631/IJEPC.644011

In addition, self-identity is in essence a self-theory which is a summary of experiences and assumptions of the relevant self and function as problem solving and explanatory frameworks (Berzonsky 1990). According to Berzosky (1992) in a bid to maintain a consolidated identity, adolescents' experience the monitoring and rehearsing of self-constructs differently. The focus of the current study was on identity styles because this study sought to find out how adolescents used the social cognitive strategy to process identity key information, negotiate identity significant problems and make personal decisions.

An informational identity style is indicated as a way in which an adolescent explore, synthesize, and thoroughly evaluate identity significant information from many different sources (Soenens et al., 2015). Adolescents with informational identity style are said to make concrete identity decisions after they explore, digest, interpret and process relevant information needed for the said decisions (Soenens et a., 2015). Such adolescents do not negotiate identity conflicts or form commitment without processing self-relevant information as a result the commitment that they make is grounded on appropriate involvement, desire to self-explore and are open to change (Berzonsky, 1992). They depict cognitive complexity, are autonomous, cognitive persistence, decisional vigilance display mature interpersonal relationships, are problem solving oriented, focused to meet their goals, a high educational performance standard and a high sense of integrity (Berzonsky, 2008).

A normative identity style is where an adolescent adopt the ideas of significant other for instance, parents and family without questioning or putting any exploratory efforts, they seek opinion of others before making decisions, attach a lot of importance to core values and beliefs that were impacted by others and this makes them less open to information that may threaten these ideologies hence they strive to preserve their existing organized and committed identities (Berzonsky, 2004). In addition, they embrace cultural conservatism, need for structure, purpose for education and they emphasize collective components for instance religion and family (Dollinger, 2010).These results to the development of dependency syndrome which curtails them from creating their own values (Berzonsky, 2004).

Adolescents who adopt diffuse avoidant identity style procrastinate and tend to push ahead decisions associated with identity, delay in handling conflicts and dealing with related individual challenges as much as possible (Berzonsky, 2004). In addition, they never engage in self-reflection, use maladaptive methods in making decisions, panic in situations, display high levels of passive identity formation, are likely to harbor feelings of shame, depict conduct disorders and hyperactivity challenges (Adams, 2001). Moreover, such adolescents are said to have a low self-esteem, limited self-control, associated with an exterior locus of control and rely mostly on their emotions (Berzonsky 2008). According to Soenens et al. (2015) adolescents adopt various identity styles as a way of formulating a sense of identity.

Commitment is also a key aspect, in identity style formulation and entails providing adolescent with a sense of purpose (Berzonsky, 2004). It also involves making a deliberate firm choice of an identity orientation and being part of important activities that enhance the implementation of that choice (Crocetti et al., 2014). Hatano, Sugimura \& Klimstra, (2017) concurs with the latter that exploration and commitment represent exploring a variety of alternatives and commitment as the actual making of choices respectively, similarly Ntoumanis et al. (2017) states that when adolescents are able to resolve their issues by being committed towards pursuing their goals, beliefs and values after exploration of a variety of areas then identity 


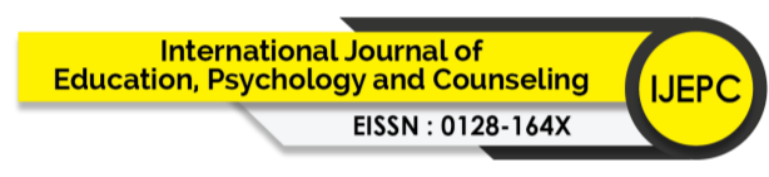

Volume 6 Issue 44 (December 2021) PP. 137-154

DOI 10.35631/IJEPC.644011

consolidation and achievement occurs. This brought to the fore the importance of adolescent identity style development which was addressed in the study.

Previous research studies stipulates that adolescents with informational and normative identity styles are optimistic and have a high self-esteem (Phillips \& Pitman, 2007) and there is a positive correlation of the two identity styles with the adolescents reports of their psychological development (Crocetti \& Shokri, 2010). This finding concurred with a study that sort to find out the relationship between identity styles and adolescent development: the findings indicated that informational identity style was highly associated with all components of positive adolescent wellbeing (Crocetti, Erentaite \&Zukauskiene, 2014) and added that on the contrary, diffuse avoidant identity style had the lowest adolescent development levels (Crocetti, Erentaite \&Zukauskiene, 2014). This was a crucial aspect that the study intended to find out.

Gender differences is in consistent for example a previous study depicted that adolescent boys tend to use less informational identity style than adolescent girls (Soenens, Luyckx \& Goosens, 2010) in contrast to a study by Smits (2008) which indicated that adolescent boys adopt more of informational identity style than adolescent girls (Smits, 2008) while adolescent boys tend to have a higher diffuse avoidant style than adolescent girls (Berzonsky, 2004)). However, there was no gender difference in informational and normative identity styles (Berzonsky, 2008). Similarly, Smits (2008) concurs with the former findings that adolescent boys adopt a greater diffuse avoidant style than adolescent girls. The study explored identity styles that were adopted by both boys and girls. In addition, the study sought to establish relationship between parental attachment styles and adolescent identity style.

Empirical research studies have indicated enough evidence that relationship between parents and adolescents greatly enhance exploration and formation of identity during adolescent years (Kiralp, 2017). This is line with earlier studies Smits et al. (2008) who indicated that an open, flexible and exploration of identity is enhanced by parental nurturance. According to Cassidy et al. (2018) adolescents with a secure attachment develop an internal working model, positive feelings of worth and a high sense of identity which enable them build relationship with others in future. This finding supports the concept of attachment theory that efficient parenting enhance adolescents' sense of self and relationship with others (Benson, 2013). Similarly, Kiralp (2017) stated that attachment style adopted by an adolescent depicts itself in their selfidentity and in relationships with others. The opposite is true that when parent child relationship is insecure the child formation of internal model is affected and has a detrimental impact in adolescents and future relationships (Cassidy et al., 2018). Secure parent adolescent attachment encourages feelings and belief that contributes to life meaning and a stable coherent identity (Mikulincer \& Shaver, 2013) while insecure parent adolescent relationship is detrimental to the formation of a stable adolescent self-identity (Mikulincer \&Shaver, 2013). Imtiaz \& Naqui (2012) study on parental attachment and identity styles among adolescents in Pakistan indicated that it was positively associated with adolescents' informational, normative identity styles and commitment, on the other hand, parental attachment was negatively correlated with adolescent diffuse avoidant identity style. Likewise, an earlier study was done on perceived parenting patterns and identity styles among 674 Dutch adolescents (Soenens et al., 2008). The findings indicated there was a significant relationship between parental attachment and adolescent identity styles development while (Ghorbani \& Abdullah, 2015) found out that family relationships had an impact on adolescents' identity style development in a study done among Iran adolescents. 


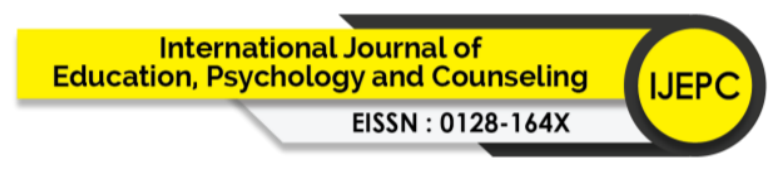

Volume 6 Issue 44 (December 2021) PP. 137-154

DOI 10.35631/IJEPC.644011

Kaniusonyte \& Zukauskience (2017) did a study with 153 adolescents in Lithuanian on relationships with parents identity styles and positive adolescent development, the findings indicated that parents positive parental attachment with adolescent play a significant role in adolescents successful adjustment, enhance adequate identity management and overall adolescent development. Further studies done among adolescents in South Africa on the effect of parental involvement on adolescent identity styles are in line with previous findings that informational identity style is positively enhanced by parental support (Heerden, 2018). The above reviewed literature seemed to emphasize the significance of parental attachment to adolescent identity style development and this was explored in the study.

There are differences between fathers and mothers in the way they individually relate to adolescent (Sumuolis et al., 2014) and how each of them influence on adolescents identity styles (Saimoulis et al., 2001). Mothers enhance adolescent information identity by encouraging broad exploration by their maturing adolescent while fathers discourage the adolescent from commitment and making definite choices (Sesito and Sica, 2014). Likewise, maternal attachment predicts the informational and normative identity styles in adolescents (Ratner, 2014).

Similarly, Heerden (2018) concurs with this findings that maternal modelling and instruction is a positive predictor of informational identity style development in adolescents' this premise was earlier supported by Smits (2008) study sort to establish the relationship between vital dimensions of perceived parenting support and psychological control and identity styles among adolescents. However, Ratner (2014) study recommended further research to investigate the variables that keep fathers from embracing a significant relationship with identity styles a suggestion Heerden (2018) concurs with that a lot of studies should be conducted on father involvement and adolescent identity style development. This gap was filled in the current study because it explored separately how mother and father attachment styles influenced adolescent identity style development.

Research studies in Kenya on parental attachment on adolescent's identity styles have been scant not only those studies focusing on adolescents in traditional biological families but also those in blended families. Most studies have related parental adolescent attachment with variables for instance; academic performance, social adjustment, psychological wellbeing, conduct disorders, social behavior and other behavior problems. While others have discussed Marcia identity status and Erickson Ego identity. For instance, these studies were pertinent to the current study in that they indicated the importance of parent adolescent relationship. However, none had explored how parental attachment styles influenced adolescent identity styles development from a blended family perspective, therefore this study was crucial.

\section{Research Methodology}

\section{Sample Size and Sampling Design}

Sampling is a process of selecting a number of individuals or objects from a population such that the selected group contains elements representative of the characteristics found in the entire group (Kombo \& Tromp, 2013). 


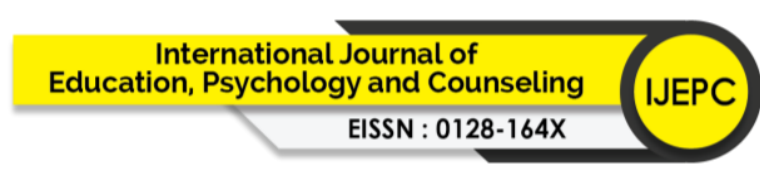

Volume 6 Issue 44 (December 2021) PP. 137-154

DOI 10.35631/IJEPC.644011

The study employed multistage sampling technique comprising of simple random sampling, survey method of sampling, purposive sampling and also inclusive/exclusive criteria. Simple random sampling was used to sample 3 Sub Counties these were; Limuru, Thika, and Kiambaa out of the 12 sub counties in Kiambu County.

Orodho (2013) state that a representative sample ought to constitute at least $30 \%$ of the population when the population of the study is small and $10 \%$ if the population is large. In order to acquire a fair representation of sub counties a sampling index of $0.3(30 \%)$ was used to select the 3 sub counties. In addition lists of all public secondary schools in the three sub counties were obtained from the respective education offices in Kiambu County and simple random sampling was used to select a total of 9 schools from the 3 sub counties.

The second stage entailed selecting students to be included in the study. Survey sampling technique was adopted because the total population of adolescents that came from blended families was unknown. Prior to the actual data collection day the researcher visited the 9 sampled schools to determine the population of adolescents from blended families with the assistance of school counselors. Simple random sampling was used to determine the 5 classes to be sampled in each of the 9 schools. The 5 classes had a population of 55 students each. A short questionnaire with demographic data of students was issued to all the students (2475) in a bid to elicit the adolescents from the said classes that came from blended families in the 9 schools. A total number of 208 adolescents from blended families in the 9 schools was elicited and this was considered a sufficient sample size. In Marriage and Family research studies, a sample size of between 150 to 200 is enough for a study (Sprenkle \& Piercy, 2005). All the 208 students were issued with questionnaires based on the standardized tools. The inclusion/exclusion criteria was;

i) The students were 13-19 years of age

ii) The student should be from a blended family household where one of the parent was either a step father or a step mother.

The third stage of the sampling process involved selecting of focus group members and school counselors. Simple random sampling was used to sample 24 participants to form 4 focus groups comprising of 6 participants each (Johnson \& Christen, 2004). 4 focus groups were purposively selected from 4 of the 9 sampled schools this is consistent with (Leech \& Zoran, 2007) who recommended that 3 to 6 groups are adequate to bring out most prevalent themes within any given data set. Two of the focus groups comprised of females/ males who live with step mothers while the other two groups were comprised of female/ male students who reside with step fathers. The focus groups members were grouped as homogenous groups to enhance communication. Also 4 counselors were purposively selected from the 9 schools for in-depth interview schedule. The counselors were purposively sampled to elicit professional counselors because not all counselors in schools are normally trained in counselling. 


\section{Findings}

\section{Influence of Attachment Styles on Establishment of Identity among Adolescents from Blended Families}

\section{Descriptive of Identity Style as Dependent Variable}

The dependent variable of the study was the identity style which was measured by Identity Style Inventory (ISI-4) Bezonsky (2011). The Identity Style Inventory (ISI-4) has 48 questions measured in four likert scale; 1 to 4 . The descriptive statistical tests conducted were Mean (M) and Standard deviation (SD). The mean value result for each question was categorized as follows: $\mathrm{M}<1.5$ as Not at all like me, $\mathrm{M}=>1.5$, $<2.5$ as Not like me, $\mathrm{M}=>2.5,<3.5$ as somewhat like me and lastly $\mathrm{M}=>3.5$ as Very much like me. The result was divided into three clusters of parents; the step father, the step mother and the combined (all parents) for each of the four components presenting identity of the adolescents.

As indicated on table 1 there was similarity at which the four component presenting identity were ranked by adolescents living with step father, mother and the combination of the two. The rate of each of the component was obtained by summation of the response. Generally, information orientation had the highest ranking $(\mathrm{M}=34.7, \mathrm{SD}=5.0)$, followed by commitment $(\mathrm{M}=28.3, \mathrm{SD}=4.4)$, normative orientation $(\mathrm{M}=25.6, \mathrm{~S}=4.0)$ and lastly, diffuse orientation $(\mathrm{M}=23.5, \mathrm{SD}=5.3)$. This was similar ranking by adolescents living with step father and adolescents living with step mothers.

Table 1 Mean of Identity Style

\begin{tabular}{|l|r|r|r|r|r|r|}
\hline & \multicolumn{2}{|l|}{ Step Father } & \multicolumn{2}{l|}{ Step Mother } & \multicolumn{2}{l|}{ All Parents } \\
\hline & M & SD & M & SD & M & SD \\
\hline $\begin{array}{l}\text { Information } \\
\text { Orientation }\end{array}$ & 34.6175 & 4.48891 & 34.8937 & 5.60301 & 34.7344 & 4.97967 \\
\hline $\begin{array}{l}\text { Normative } \\
\text { Orientation }\end{array}$ & 25.8763 & 3.80429 & 25.2249 & 4.29324 & 25.6007 & 4.02130 \\
\hline $\begin{array}{l}\text { Diffuse } \\
\text { Orientation }\end{array}$ & 24.1193 & 5.22221 & 22.6864 & 5.27621 & 23.5130 & 5.28030 \\
\hline Commitment & 28.0174 & 4.07213 & 28.6447 & 4.70360 & 28.2828 & 4.35060 \\
\hline
\end{tabular}

\section{Correlation Test for Identity Style and Attachment Style}

Correlation test was conducted to test for significant relationship between the identity as dependent variable and attachment style as the independent variable of study. Table 2 shows the correlation between attachment style components and adolescents identity style based on the step parents of adolescents.

Information orientation of adolescents living with their step mother had significant relationship with all the attachment styles; positive relation with parental trust $(r=.288, p<.05)$ and parental communication $(r=.266, p<.05)$ but negative relation with parental alienation $(r=-.212$, $p<.05)$. However, the information orientation of adolescents living with their step father had no significant relationship ( $p>.05)$ with all the attachment styles. Similarly, commitment of adolescents living with their step mother had significant relationship with all the attachment 


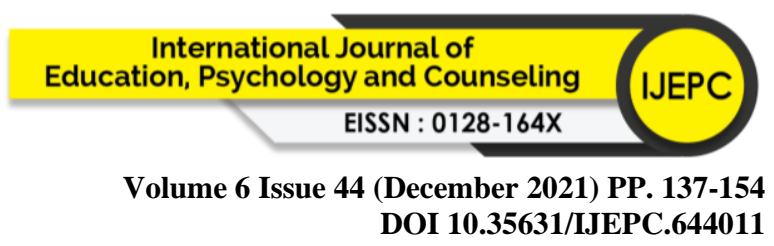

styles; positive relation with parental trust $(r=.278, p<.05)$ and parental communication $(r$ $=.348, p<.05)$ but negative relation with parental alienation $(r=-.399, p<.05)$. However, the commitment of adolescents living with their step father had no significant relationship $(p>.05)$ with all the attachment styles. Adolescents living with step father had only significant relation on diffuse orientation and parental alienation $(r=.191, p<.05)$ but not significant with parental communication and trust. Normative orientation of both adolescents living with step mother and those living with step father had no significant relationship ( $p>.05)$ with all the attachment styles.

Table 2 Correlation Test for Identity Style and Attachment Style

\begin{tabular}{|c|c|c|c|c|c|c|c|c|c|}
\hline & & $\begin{array}{l}\text { Inforn } \\
\text { Orien }\end{array}$ & $\begin{array}{l}\text { nation } \\
\text { tation }\end{array}$ & $\begin{array}{l}\text { Norm } \\
\text { Orien }\end{array}$ & $\begin{array}{l}\text { native } \\
\text { tation }\end{array}$ & $\begin{array}{r}\text { Diff } \\
\text { Orien }\end{array}$ & $\begin{array}{l}\text { fuse } \\
\text { ntation }\end{array}$ & Commi & itment \\
\hline & & $\begin{array}{l}\text { step } \\
\text { father }\end{array}$ & \begin{tabular}{|c|} 
step \\
mother
\end{tabular} & \begin{tabular}{l|} 
step \\
father
\end{tabular} & \begin{tabular}{|c|} 
step \\
mother
\end{tabular} & $\begin{array}{l}\text { step } \\
\text { father }\end{array}$ & $\begin{array}{c}\text { step } \\
\text { mother }\end{array}$ & \begin{tabular}{|c|} 
step \\
father
\end{tabular} & \begin{tabular}{|l|} 
step \\
mother
\end{tabular} \\
\hline Parental trust & Pearson Correlation & .034 & $.288^{* * *}$ & -.066 & .144 & -.069 & \begin{tabular}{|l|}
-207 \\
\end{tabular} & .104 & $.278^{* *}$ \\
\hline & Sig. (2-tailed) & .714 & .006 & .475 & 181 & .454 & .053 & .257 & .009 \\
\hline & $\mathrm{N}$ & 120 & 88 & 120 & 88 & 120 & 88 & 120 & 88 \\
\hline Parental & Pearson Correlation & .108 & $.266^{*}$ & .072 & .194 & -.096 & -208 & .146 & $.348^{* * 1}$ \\
\hline communication & Sig. (2-tailed) & 240 & .012 & .434 & .070 & .296 & .051 & .111 & .001 \\
\hline & $\mathrm{N}$ & 120 & 88 & 120 & 88 & 120 & 88 & 120 & 88 \\
\hline Parental & Pearson Correlation & -.026 & $-.212^{*}$ & -.120 & -.186 & $.191^{*}$ & $.308^{* * *}$ & -.156 & $-.399^{* * *}$ \\
\hline alienation & Sig. (2-tailed) & .776 & \begin{tabular}{|l|}
.047 \\
\end{tabular} & .193 & .082 & .037 & .004 & $\begin{array}{l}.090 \\
\end{array}$ & .000 \\
\hline & $\mathrm{N}$ & 120 & 88 & 120 & \begin{tabular}{|c|}
88 \\
\end{tabular} & 120 & 88 & 120 & 88 \\
\hline
\end{tabular}

\section{T-test and MANCOVA on Influence of Attachment Style on Identity Style}

The mean comparison of the adolescents' identity style based on the step parent showed there were no difference of the mean value between adolescents living with step mother and adolescents' living with step father on information orientation, normative orientation and commitment. However, there was small difference on mean value of diffuse orientation; step father $(M=24.1, S D=5.2)$ and step mother $(M=22.7, S D=5.3)$. Table 3 shows the mean value, the standard deviation value of identity style of step parent.

Table 3 Mean of Identity Style and Step Parent

\begin{tabular}{|l|l|r|r|r|r|}
\hline & $\begin{array}{l}\text { step mother or } \\
\text { step faher }\end{array}$ & $\mathrm{N}$ & Mean & Std. Deviation & $\begin{array}{c}\text { Std. Error } \\
\text { Mean }\end{array}$ \\
\hline \multirow{2}{*}{ Information Orientation } & Step Father & 120 & 34.6175 & 4.48891 & .40978 \\
\cline { 2 - 6 } & Step Mother & 88 & 34.8937 & 5.60301 & .59728 \\
\hline \multirow{2}{*}{ Normative Orientation } & Step Father & 120 & 25.8763 & 3.80429 & .34728 \\
\cline { 2 - 6 } & Step Mother & 88 & 25.2249 & 4.29324 & .45766 \\
\hline \multirow{2}{*}{ Diffuse Orientation } & Step Father & 120 & 24.1193 & 5.22221 & .47672 \\
\cline { 2 - 6 } & Step Mother & 88 & 22.6864 & 5.27621 & .56245 \\
\hline \multirow{2}{*}{ Commitment } & Step Father & 120 & 28.0174 & 4.07213 & .37173 \\
\cline { 2 - 6 } & Step Mother & 88 & 28.6447 & 4.70360 & .50141 \\
\hline
\end{tabular}




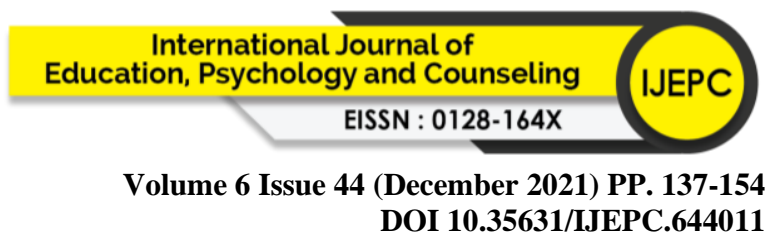

Further, a T-test result showed the mean difference of the identity style between adolescents living with step mother compared to adolescents living with step father was only statistically significant at diffuse orientation; step father $(M=24.1, S D=5.2)$ and step mother $(M=22.7$, $\mathrm{SD}=5.3) t(206)=1.43, p<0.05$. This shows the only identity style with significance difference on mean value based on step parent was diffuse orientation. Table 4 shows this result.

Table Error! No text of specified style in document. T-Test for Identity Style and Step

Parents

\begin{tabular}{|c|c|c|c|c|c|c|c|c|c|c|}
\hline & \multicolumn{2}{|c|}{$\begin{array}{c}\text { Levene's } \\
\text { Test for } \\
\text { Equality of } \\
\text { Variances }\end{array}$} & \multicolumn{7}{|c|}{ t-test for Equality of Means } \\
\hline & & \multirow[t]{2}{*}{$\mathrm{F}$} & \multirow[t]{2}{*}{ Sig. } & \multirow[t]{2}{*}{$\mathrm{t}$} & \multirow[t]{2}{*}{$\mathrm{df}$} & \multirow[t]{2}{*}{$\begin{array}{c}\text { Sig. } \\
(2- \\
\text { tailed })\end{array}$} & \multirow[t]{2}{*}{$\begin{array}{c}\text { Mean } \\
\text { Difference }\end{array}$} & \multirow[t]{2}{*}{$\begin{array}{l}\text { Std. Error } \\
\text { Difference }\end{array}$} & \multicolumn{2}{|c|}{$\begin{array}{c}95 \% \\
\text { Confidence } \\
\text { Interval of the } \\
\text { Difference }\end{array}$} \\
\hline & & & & & & & & & Lower & Upper \\
\hline \multirow[b]{2}{*}{$\begin{array}{l}\text { Information } \\
\text { Orientation }\end{array}$} & $\begin{array}{l}\text { Equal } \\
\text { variances } \\
\text { assumed }\end{array}$ & 0.28 & 0.60 & -0.39 & 206.00 & 0.69 & -0.28 & 0.70 & -1.66 & 1.10 \\
\hline & $\begin{array}{l}\text { Equal } \\
\text { variances } \\
\text { not } \\
\text { assumed }\end{array}$ & & & -0.38 & 161.95 & 0.70 & -0.28 & 0.72 & -1.71 & 1.15 \\
\hline \multirow[b]{2}{*}{$\begin{array}{l}\text { Normative } \\
\text { Orientation }\end{array}$} & $\begin{array}{l}\text { Equal } \\
\text { variances } \\
\text { assumed }\end{array}$ & 1.24 & 0.27 & 1.16 & 206.00 & 0.25 & 0.65 & 0.56 & -0.46 & 1.76 \\
\hline & $\begin{array}{l}\text { Equal } \\
\text { variances } \\
\text { not } \\
\text { assumed }\end{array}$ & & & 1.13 & 173.89 & 0.26 & 0.65 & 0.57 & -0.48 & 1.79 \\
\hline \multirow[b]{2}{*}{$\begin{array}{l}\text { Diffuse } \\
\text { Orientation }\end{array}$} & $\begin{array}{l}\text { Equal } \\
\text { variances } \\
\text { assumed }\end{array}$ & 0.36 & 0.55 & 1.95 & 206.00 & 0.05 & 1.43 & 0.74 & -0.02 & 2.88 \\
\hline & $\begin{array}{l}\text { Equal } \\
\text { variances } \\
\text { not } \\
\text { assumed }\end{array}$ & & & 1.94 & 186.52 & 0.05 & 1.43 & 0.74 & -0.02 & 2.89 \\
\hline \multirow[b]{2}{*}{ Commitment } & $\begin{array}{l}\text { Equal } \\
\text { variances } \\
\text { assumed }\end{array}$ & 1.45 & 0.23 & -1.03 & 206.00 & 0.31 & -0.63 & 0.61 & -1.83 & 0.58 \\
\hline & $\begin{array}{l}\text { Equal } \\
\text { variances } \\
\text { not } \\
\text { assumed }\end{array}$ & & & -1.01 & 171.13 & 0.32 & -0.63 & 0.62 & -1.86 & 0.60 \\
\hline
\end{tabular}

To answer the research question; the influence of attachment style on identity style of adolescents, MANCOVA test as a multivariate analysis was conducted. The key variables for the multivariate was; the identity style as the dependent variable, the attachment style as independent variable and step parents as fixed factors. Table 5 shows the Multivariate test output result of one-way MANCOVA. The point of intercept between the attachment style and Copyright $\odot$ GLOBAL ACADEMIC EXCELLENCE (M) SDN BHD - All rights reserved 


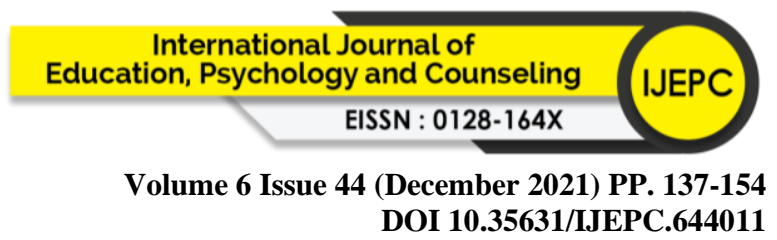

the identity based on the Wilk's Lambda result shows it was statistically significant $(p<.05)$. Therefore, identity style based on attachment style was statistically difference $F(4,202)=$ $1.242, p<.05$; Wilk's $\Lambda=0.976$, partial $\eta^{2}=.024$. This means attachment style influenced identity style. Further, the dependence on attachment style based on adolescents' step parent was not significant.

Table 5. Multivariate Test on Influence of Attachment Style on Identity Style

\begin{tabular}{|c|c|c|c|c|c|c|c|}
\hline \multicolumn{2}{|l|}{ Effect } & Value & $\mathrm{F}$ & $\begin{array}{l}\text { Hypothes } \\
\text { is df }\end{array}$ & Error df & Sig. & $\begin{array}{c}\text { Partial Eta } \\
\text { Squared }\end{array}$ \\
\hline \multirow{4}{*}{ Intercept } & Pillai's Trace & .971 & $1663.743^{\mathrm{b}}$ & 4.000 & 202.000 & .000 & .971 \\
\hline & $\begin{array}{l}\text { Wilks' } \\
\text { Lambda }\end{array}$ & .029 & $1663.743^{b}$ & 4.000 & 202.000 & .000 & .971 \\
\hline & $\begin{array}{l}\text { Hotelling's } \\
\text { Trace }\end{array}$ & 32.945 & $1663.743^{b}$ & 4.000 & 202.000 & .000 & .971 \\
\hline & $\begin{array}{l}\text { Roy's Largest } \\
\text { Root }\end{array}$ & 32.945 & $1663.743^{b}$ & 4.000 & 202.000 & .000 & .971 \\
\hline \multirow{4}{*}{ attachment } & Pillai's Trace & .084 & $4.650^{\mathrm{b}}$ & 4.000 & 202.000 & .001 & .084 \\
\hline & $\begin{array}{l}\text { Wilks' } \\
\text { Lambda }\end{array}$ & .916 & $4.650^{\mathrm{b}}$ & 4.000 & 202.000 & .001 & .084 \\
\hline & $\begin{array}{l}\text { Hotelling's } \\
\text { Trace }\end{array}$ & .092 & $4.650^{\mathrm{b}}$ & 4.000 & 202.000 & .001 & .084 \\
\hline & $\begin{array}{l}\text { Roy's Largest } \\
\text { Root }\end{array}$ & .092 & $4.650^{\mathrm{b}}$ & 4.000 & 202.000 & .001 & .084 \\
\hline \multirow{4}{*}{$\begin{array}{l}\text { Stepmother or } \\
\text { stepfather }\end{array}$} & Pillai's Trace & .024 & $1.242^{\mathrm{b}}$ & 4.000 & 202.000 & .295 & .024 \\
\hline & $\begin{array}{l}\text { Wilks' } \\
\text { Lambda }\end{array}$ & .976 & $1.242^{\mathrm{b}}$ & 4.000 & 202.000 & .295 & .024 \\
\hline & $\begin{array}{l}\text { Hotelling's } \\
\text { Trace }\end{array}$ & .025 & $1.242^{\mathrm{b}}$ & 4.000 & 202.000 & .295 & .024 \\
\hline & $\begin{array}{l}\text { Roy's Largest } \\
\text { Root }\end{array}$ & .025 & $1.242^{\mathrm{b}}$ & 4.000 & 202.000 & .295 & .024 \\
\hline \multicolumn{8}{|c|}{ a. Design: Intercept + attachment_+ stepmother or father } \\
\hline
\end{tabular}

Further analysis on the test between subject effects shows that attachment style has a statistically significant effect on three of the identity style components. In chronological order based on the influence, Commitment $\left(F(1,205)=13.960 ; p<.05\right.$; partial $\left.\eta^{2}=.064\right)$, Diffuse orientation $\left(F(1,205)=6.994 ; p<.05\right.$; partial $\left.\eta^{2}=.033\right)$, and Information orientation $(F(1$, $205)=6.226 ; p<.05 ;$ partial $\left.\eta^{2}=.029\right)$. There was no influence on Normative orientation $(F$ $(1,205)=2.479 ; p>.05$; partial $\left.\eta^{2}=.012\right)$. This shows attachment style affects the commitment, diffuse orientation and information orientation as identity style of adolescents as indicated on table 6 . 
Table 6. Test between Subjects Effect of Attachment Style on Identity Style

\begin{tabular}{|c|c|c|c|c|c|c|c|}
\hline \multicolumn{8}{|c|}{ Tests of Between-Subjects Effects } \\
\hline Source & Dependent Variable & \begin{tabular}{|l|} 
Type III \\
Sum of \\
Squares \\
\end{tabular} & $\mathrm{df}$ & \begin{tabular}{|c|} 
Mean \\
Square
\end{tabular} & $\mathrm{F}$ & Sig. & $\begin{array}{c}\text { Partial } \\
\text { Eta } \\
\text { Squared } \\
\end{array}$ \\
\hline \multirow{4}{*}{$\begin{array}{l}\text { Corrected } \\
\text { Model }\end{array}$} & $\begin{array}{l}\text { Information } \\
\text { Orientation }\end{array}$ & $155.063^{\mathrm{a}}$ & 2 & 77.531 & 3.193 & .043 & .030 \\
\hline & $\begin{array}{l}\text { Normative } \\
\text { Orientation } \\
\end{array}$ & $61.278^{b}$ & 2 & 30.639 & 1.911 & .151 & .018 \\
\hline & Diffuse Orientation & $291.220^{c}$ & 2 & 145.610 & 5.447 & .005 & .050 \\
\hline & Commitment & $268.505^{\mathrm{d}}$ & 2 & 134.253 & 7.541 & .001 & .069 \\
\hline \multirow{4}{*}{ Intercept } & $\begin{array}{l}\text { Information } \\
\text { Orientation }\end{array}$ & 55854.141 & 1 & 55854.141 & 2300.164 & .000 & .918 \\
\hline & $\begin{array}{l}\text { Normative } \\
\text { Orientation }\end{array}$ & 31015.679 & 1 & 31015.679 & 1934.892 & .000 & .904 \\
\hline & Diffuse Orientation & 31743.096 & 1 & 31743.096 & 1187.413 & .000 & .853 \\
\hline & Commitment & 35220.674 & 1 & 35220.674 & 1978.402 & .000 & .906 \\
\hline \multirow{4}{*}{ attachment } & $\begin{array}{l}\text { Information } \\
\text { Orientation }\end{array}$ & 151.192 & 1 & 151.192 & 6.226 & .013 & .029 \\
\hline & \begin{tabular}{|l|} 
Normative \\
Orientation \\
\end{tabular} & 39.737 & 1 & 39.737 & 2.479 & .117 & .012 \\
\hline & Diffuse Orientation & 186.980 & 1 & 186.980 & 6.994 & .009 & .033 \\
\hline & Commitment & 248.529 & 1 & 248.529 & 13.960 & .000 & .064 \\
\hline \multirow{4}{*}{$\begin{array}{l}\text { Step } \\
\text { mother or } \\
\text { step father }\end{array}$} & $\begin{array}{l}\text { Information } \\
\text { Orientation } \\
\end{array}$ & .002 & 1 & .002 & .000 & .993 & .000 \\
\hline & \begin{tabular}{|l|} 
Normative \\
Orientation \\
\end{tabular} & 30.923 & 1 & 30.923 & 1.929 & .166 & .009 \\
\hline & Diffuse Orientation & 63.530 & 1 & 63.530 & 2.376 & .125 & .011 \\
\hline & Commitment & 3.904 & 1 & 3.904 & .219 & .640 & .001 \\
\hline \multirow{4}{*}{ Error } & $\begin{array}{l}\text { Information } \\
\text { Orientation }\end{array}$ & 4977.948 & 205 & 24.283 & & & \\
\hline & $\begin{array}{l}\text { Normative } \\
\text { Orientation }\end{array}$ & 3286.083 & 205 & 16.030 & & & \\
\hline & Diffuse Orientation & 5480.264 & 205 & 26.733 & & & \\
\hline & Commitment & 3649.530 & 205 & 17.803 & & & \\
\hline \multirow{4}{*}{ Total } & $\begin{array}{l}\text { Information } \\
\text { Orientation }\end{array}$ & 256080.025 & 208 & & & & \\
\hline & $\begin{array}{l}\text { Normative } \\
\text { Orientation }\end{array}$ & 139669.484 & 208 & & & & \\
\hline & Diffuse Orientation & 120766.996 & 208 & & & & \\
\hline & Commitment & 170300.806 & 208 & & & & \\
\hline \multirow{3}{*}{$\begin{array}{l}\text { Corrected } \\
\text { Total }\end{array}$} & $\begin{array}{l}\text { Information } \\
\text { Orientation }\end{array}$ & 5133.011 & 207 & & & & \\
\hline & $\begin{array}{l}\text { Normative } \\
\text { Orientation }\end{array}$ & 3347.360 & 207 & & & & \\
\hline & Diffuse Orientation & 5771.484 & 207 & & & & \\
\hline
\end{tabular}


Volume 6 Issue 44 (December 2021) PP. 137-154

DOI 10.35631/IJEPC.644011

\begin{tabular}{|l|l|l|l|l|}
\hline Commitment & 3918.035 & 207 & & \\
\hline a. R Squared $=.030$ (Adjusted R Squared $=.021)$ & & \\
\hline b. R Squared $=.018$ (Adjusted R Squared $=.009)$ & \\
\hline c. R Squared $=.050$ (Adjusted R Squared $=.041)$ & \\
\hline d. R Squared $=.069$ (Adjusted R Squared $=.059)$ & \\
\hline
\end{tabular}

\section{Discussions}

To evaluate the influence of attachment styles on establishment of identity among adolescents from blended families in Kiambu County. The Correlation Test for Identity Style and Attachment Style was conducted to test for significant relationship between the identity as dependent variable and attachment style as the independent variable of study. Findings indicated that Information orientation of adolescents living with their step mother had significant relationship with all the attachment styles, positive relation with parental trust and parental communication but negative relation with parental alienation. However, the information orientation of adolescents living with their step father had no significant relationship with all the attachment styles. Similarly, commitment of adolescents living with their step mother had significant relationship with all the attachment styles; positive relation with parental trust and parental communication but negative relation with parental alienation. However, the commitment of adolescents living with their step father had no significant relationship with all the attachment styles.

Findings noted that adolescents living with step father had only significant relation on diffuse orientation and parent alienation but not significant with parent communication and trust. Normative orientation of both adolescents living with step mother and those living with step father had no significant relationship with all the attachment styles. Further to answer the research question; the influence of attachment style on identity style of adolescents, MANCOVA test as a multivariate analysis was conducted. The key variables for the multivariate was; the identity style as the dependent variable, the attachment style as independent variable and step parents as fixed factors. The point of intercept between the attachment style and the identity based on the Wilk's Lambda result showed it was statistically significant. Therefore, identity style based on attachment style was statistically difference. This meant attachment style influenced identity style. Further, the dependence on attachment style based on adolescents' step parent was not significant.

Further analysis on the test between subject effects shows that attachment style has a statistically significant effect on three of the identity style components. In chronological order based on the influence, Commitment, Diffuse orientation and Information orientation. There was no influence on normative orientation. This shows attachment style affects the commitment, diffuse orientation and information orientation as identity style of adolescents. The above findings found out that attachment styles affect identity styles formation in adolescents this is line with earlier empirical research studies that indicated enough evidence that relationship between parents and adolescents greatly enhance exploration and formation of identity during adolescent years (Kiralp \& Serin, 2017). Similarly further studies indicated that a secure parent adolescent attachment encourages feelings and belief that contributes to life meaning and a stable coherent identity (Mikulincer \& Shaver, 2013) while insecure parent adolescent relationship is detrimental to the formation of a stable adolescent self-identity. Likewise, an earlier study done on perceived parenting patterns and identity styles among 674 Dutch adolescents Soenens \& Luyckx (2008) indicated there was a significant relationship Copyright (C) GLOBAL ACADEMIC EXCELLENCE (M) SDN BHD - All rights reserved 


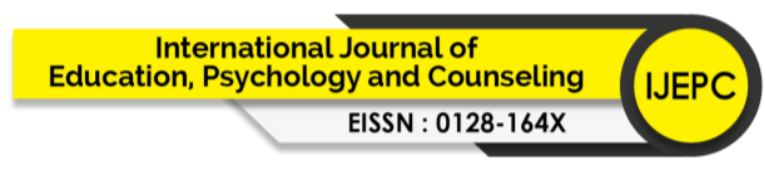

Volume 6 Issue 44 (December 2021) PP. 137-154

DOI 10.35631/IJEPC.644011

between parental attachment and adolescent identity styles development while Ghorbani \& Abdullah (2015) found out that family relationships had an impact on adolescent's identity style development in a study done among Iran adolescents. This shows the importance of parental attachment in enhancing adolescents' identity style formation.

Further the study findings also indicated that attachment styles only affect the information, diffuse avoidant and commitment identity styles but does not affect normative orientation. This was contrary to Imtiaz \& Naqui (2012) study on parental attachment and identity styles among adolescents in Pakistan that indicated that parental attachment was positively associated with adolescents' informational, normative identity styles and commitment, on the other hand, parental attachment was negatively correlated with adolescent diffuse avoidant identity style. This may mean that adolescents in Pakistan adopt normative identity styles indicating they adopt ideas of significant others than the Kenyan adolescents. This could be attributed to the almost homogenous culture and religious affiliation in Pakistan as opposed to the diverse multicultural and religious scenario prevailing in Kenya.

The study also found out that adolescents living with step mothers had significantly higher parental trust and parental communication and this has led to adolescents having a secure attachment with the step mothers and this has resulted to enhanced information and commitment identity styles development of adolescents as compared to adolescents living with step fathers. Similarly studies have shown that mothers enhance adolescent information identity by encouraging broad exploration by their maturing adolescent while fathers discourage the adolescent from commitment and make definite personal choices (Sesito \&Sica, 2014). An assertion confirmed (Respondent FGD 9). "My step father says he knows what decisions are good for me and is aware of how adolescent go astray. Little does he know that taking alcohol is a decision I made”. Likewise, Heerden (2018) concurs with this findings that maternal modelling and instruction is a positive predictor of informational identity style development in adolescents, on the contrary Ratner (2014) revealed that maternal attachment predicts the normative identity styles in adolescents but the findings of the study refuted this assertion by indicating that attachment styles do not influence the establishment of adolescent normative identity style regardless of whether an adolescent lives with a step mother or a step father.

Study findings also revealed that dysfunctional step families are a recipe to adolescent identity problem, this happens when parents especially step fathers are alienated from their girls which leads to the daughters loneliness and this makes yield to negative peer pressure as they seek solace from friends who in turn mislead them because they are unable to make personal decisions an observation that was made by (Counselor) who reported that two of the girls from her school had been sent away because of lesbianism. "When these girls were referred to me for counselling I discovered they came from step families that were very dysfunctional, one of the girls step father subjects her biological mother to domestic violence while the other girl lives a solitary life because she has no close relationship with her step father". The counselor deduced that these girls had identity problems. All the other counselors concurred and also emphasized that homosexuality was common in schools and it is a reflection of dysfunctional families. This explains the importance of parents creating a close relationship with adolescents to strengthen informational and commitment identity styles so that they cease being swayed away by other peers. Dumas, Ellis \& Wolfe (2012) concurs with this premise that the advantage 


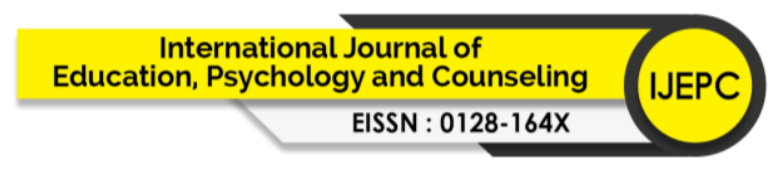

Volume 6 Issue 44 (December 2021) PP. 137-154

DOI 10.35631/IJEPC.644011

of identity style development process is that it enables teenagers avoid getting carried away by friends in making wrong choices easily because they have developed appropriate identity.

In addition, study findings depicted that information and commitment orientation of adolescents living with their step fathers had no significant relationship with parental trust and parental communication. Further findings noted that adolescents living with step fathers had only significant relation on diffuse orientation and parental alienation. This implied that step fathers adopt categories of insecure attachment in relating with adolescents and this has resulted to distant relationships. This premise is in line with Heerden (2018) assertion that a lot of studies should be conducted on father involvement and adolescent identity style development. Similarly Ratner (2014) study recommended further research to investigate the variables that keep fathers from embracing a significant relationship with identity styles a suggestion. This gap was partially filled in the current study because it explored separately how mother and father attachment styles influenced adolescent identity style development though from a blended family perspective.

\section{Conclusions}

The study concludes that; step mothers influence the development of adolescents' information and commitment identity styles unlike the step fathers who influence adolescents diffuse avoidant identity style. Adolescents living with step mothers had higher levels of parental trust and parental communication as compared to step fathers whose parental alienation levels were high. Step parents' attachment styles influence adolescents' information, commitment and diffuse avoidant identity styles but not normative identity style. Step parents should adopt secure attachment styles other than insecure attachment to enhance appropriate development of adolescent identity styles and that step fathers should go an extra mile in building positive relationships with adolescents.

\section{Recommendations}

These recommendations are made to benefit Ministry of Education, counselors, parents, families and society at large.

\section{Ministry of Education}

Should have mechanisms in place that caters for unique needs of adolescents. The Ministry should deliberately institute a counselling division within its structures with representations at all levels from the headquarters all the way to the individual schools. This counselling divisions should be empowered through appropriate and adequate human and material resources to carry out its functions. As a bare minimum, the ministry should deploy trained counselors who are able to counsel adolescents' from blended families.

\section{Counselors}

School counselors should be appropriately trained and sensitized on the need to look out for issues pertaining to adolescents from blended families as opposed to the general school fraternity. This is because from the research findings adolescents from blended families encounter many challenges that affect their identity style development compared to adolescents living with both biological parents.

\section{Parents, Families And Society}

Should embrace the aspect of blended families in order to build healthy families and society. Step parents should embrace step children as early as possible after joining the blended families 


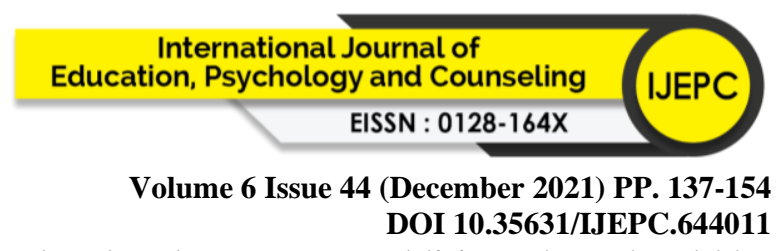

so as to enhance their establishment of identity styles development. In addition, they should be psycho educated on the unique aspects of blended families.

\section{Further Research}

Studies should be conducted on father involvement and establishment of adolescent identity style development, and investigate the variables that keep especially step fathers from embracing appropriate relationship with adolescents.

\section{References}

Adams, G. R., \& Fitch, S. A. (2001). Ego stage and identity status development: A consequential analysis. Journal of Personality and Social psychology, 43, 574-583.

Allgood, S. M., Beckert, T. E., \& Peterson, C. (2012). The role of father involvement in the perceived psychological well being of young adult daughters: A retrospective study. North American Journal of psychology, 14 (1), 95-100.

Armsden, G. C., \& Greenberg, M. T. (1987). The Inventory of Parent and Peer Attachment: Individual differences and their relationship to psychological well-being in adolescence. Journal of Youth and Adolescence, 16(5), 427-54.

Berzonsky, M. D. (1989). Identity style: Conceptualization and measurement. Journal of Adolescent Research, 4(3), 268-82.

Berzonsky, M. D. (1992). Identity Style Inventory (ISI-3): Revised version. Unpublished measure, Department of Psychology, State University of New York, Cortland, NY.

Berzonsky, M. D. (2004). Identity style, parental authority, and identity commitment. Journal of Youth and Adolescence,

Berzonsky, M.D. (2008). Identity formation. The role of identity processing style and cognitive processes: personality and individual differences, 44(3), 645-655. https://doi:org/10.1016/j.peud.2007.09.024.

Berzonsky, M.D., Soenens, B., Luyckx, K., Smits, I., Papini, D.R., \& Goosens, L. (2013). Development and validation of the revised identity style inventory (ISI-N): Factor structure, Reliability and validity. Psychological assessment. Advance Online Publication, https://doi.org/10.1037/90032642

Berzonsky, M.D., \& Papini, D.R. (2014). Identity processing styles and value orientations: The mediation role of self-regulation and identity commitment. Identity 14, 96-112 https://doi.org/10.1080/152834882013858228

Berzonsky, M.D., \& Ferran, J.R. (2009). A diffuse avoidant identity processing style: strategic avoidance or self-confusion. Identity 9,145-158. https://doi.org10.1080/15283480802683607

Berzonsky, M.D. (2011). A social cognitive perspective on identity construction. In handbook of identity theory and research, eds S.J. Schwartz. K. Luyckx and K.V.L. Vignoles (New York, NY: springer) 55-76

Berzonsky, M.D. (1990). Self-construction across the life span: a process view of identity development in advances in personal construct psychology. VDI. Leds G.H. Neimeyer and R.A. Neimeyer (Greenwich, CT. JAI Press), 155-186

Bosch, L. \& Card, N. (2011).A meta-analytic review of Berzonsky's Identity Style Inventory(ISI).Journal of Adolescence, 35, 333-343.

Bowlby, J. (1969). Attachment and loss (Vol. 1). New York, NY: Basic Books, Inc.

Brenning, K. M. \& Braet, C. (2013). The motion regulation model of attachment: An emotion-specific approach. Journal of Personal Relationship, 20(1), 107-123. 


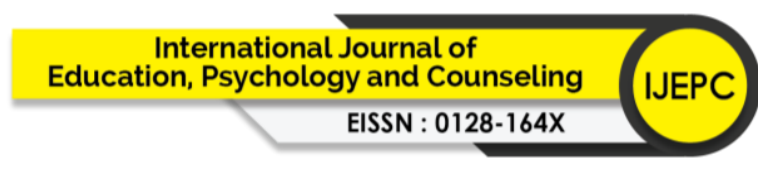

Volume 6 Issue 44 (December 2021) PP. 137-154

DOI 10.35631/IJEPC.644011

Bretherton, I., \& Munholland, K.A. (2008). Internal Working Models in Attachment Relationships. Elaborating a central construct in attachment theory In Cassidy \& P. R.

CrocettI, E.,Erentaite, R., Zukguskiene, R. (2014). Identify styles, positive youth development and civic engagement in adolescence. Journal of youth adolescence, 43(11), https://doi:701007/s10964-014-0100-4.

Dollinger, G(2010). Scaling self-identity with respect to perceived social-cultural attitudes towards appearance and personality types among male and female adolescents in the age group of 16 to 25 years. The international journal of Indian psychology, 8(4) https://doi:10.25215/DIP:01/IF.3.9(ici)

Duriez, B. \&Soenens, B. (2012). Personality, Identity Styles and Religiosity: An integrative study among late and middle adolescents. Journal of Adolescence, 29, 119-135.

Erikson, E. H. (1993) Identity: Youth and Crisis. New York: Norton

Ganong, L., Coleman, M., \& Jamison, T. (2011). Patterns of stepchild-stepparent relationship development. Journal of Marriage \& Family, 73(2), 396-413.

Garneau, C., \& Pasley, K. (2017). Stress and resilience in stepfamilies today. In C. A. Ghorbani, A., Abdullah, H (2015). The correlation of personality characteristics and social factors with identity styles in adolescents of Golestan, Iran. Journal of adolescence 2(48), 1126-1134.

Ghorbani, A., Abdullah, H (2015). The correlation of personality characteristics and social factors with identity styles in adolescents of Golestan, Iran. Journal of adolescence 2(48), 1126-1134.

Hatano, K., Sugimura, K. \&Klimstra, T. (2017). Which came first, personality or identity processes during early and middle adolescence? Journal of Research in

Heerden, M. H. (2018). The effect of parental involvement on the identity styles of adolescents Semantic Scholar Psychology. Corpusid:210489.

Imtiaz, S. \&Naqvi, I. (2012). Parental attachment and identity styles among adolescents: Moderating role of gender. Pakistan Journal of Psychological Research, 27(2), 241http://etd.uwc.ac.za/ 81264.

Jain, N. (2015). Father-Daughter Attachment Pattern and its Influence on Daughter's Development. The International Journal of Indian Psychology ISSN, 2(2), 2348-5396. http://www.ijip.in

Jensen, T.M., \& Howard, M.O.(2015). Perceived step parent-child relationship quality. A systmatic review of step children's perspectives. Marriage and family review, 99-153. https://doi: 10/1080/01494929.2015.1006717r

Jensen,T. Pace, G. (2016). Step father involvement and stepfather child relationship quality: Race and parental marital status as moderators. Journal of marital ans Family Therapy, 42(4), 659-672. https://doi.org/10.1111jmft.12165.

Jimenez, A., Oliva, A., Quueija, 5. (2014). Development of emotional from adolescence to young adulthood in Spain. Journal of adolescence, 38(52), 57-67. https://doi.10.1016/j.adolescence.11.003

Kaniušonytė, G., \& Žukauskienė, R. (2018). Relationships With Parents, Identity Styles, and Positive Youth Development During the Transition From Adolescence to Emerging Adulthood. Emerging Adulthood, 6(1), 42-52. https://doi.org/10.1177/2167696817690978

Kanivsonyte, G. Zukauskiene, R. (2017). Relationships with parents, identity styles and positive youth development during the transition from adolescence to emerging adulthood. Journal of indexing of metrics. https://doi.org/10.1177/2167696817690978 


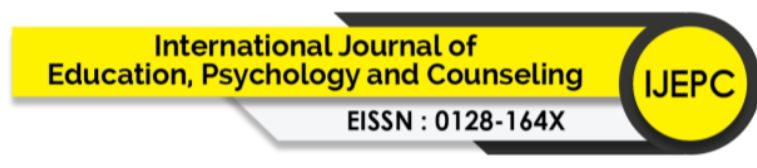

Volume 6 Issue 44 (December 2021) PP. 137-154

DOI 10.35631/IJEPC.644011

King,V \& Lindstrom,R.(2016). Continuity and change in step-father-step child closeness between adolescence and early adulthood. Journal of Marriage and Family, 78(3),730743.https//doi:10.1111/jomf.12281

King, V., Thorsen, M. L., \& Amato, P. R. (2014). Factors associated with positive relationships between stepfathers and adolescent stepchildren. Social Science Research, 47, 16-29.

Lucyckj, Suhwartz, S,. Goussens, L. (2008). Developments typologies of identity formation and adjustment on female emerging adults: A latent class growth analysis approach. Journal of research on adolescence, 18(14), 595-619. https://doi:10.11111j1532$7795.00573 \mathrm{x}$

Luyckx, K., Goossens, L. \&Soenens, B. (2006). A developmental contextual perspective on identity construction in emerging adulthood: Change dynamics in commitment formation and commitment evaluation. Developmental Psychology, 42(2), 366-380.

Luyckx, K., Schwartz, S.J., Rassart, J. \&Klimstra, T.A. (2016).Intergenerational associations linking identity styles and processes in adolescents and their parents. European Journal of Developmental Psychology, 13(1), 67-83. http://dx.doi.org/10.1080/17405629. 2015.1066668

Lucyckj, Suhwartz, S,. Goussens, L. (2008). Developments typologies of identity formation and adjustment on female emerging adults: A latent class growth analysis approach. Journal of research on adolescence, 18(14), 595-619. https://doi:10.11111j1532$7795.00573 \mathrm{x}$

Marcia, J.E. (1980). Identity in adolescence. In: J. Adelson [ed.]. Handbook of adolescent psychology [pp. 159-187]. New York, NY., USA: Wiley.

Martiny, S. E., \& Rubin, M. (2016). Towards a clearer understanding of social identity theory: self-esteem hypothesis. Contemporarily global perspective, 19-32. https://doi.org/10.10071931929869-62

Maunder, R., \& Monks, C. (2018). Friendships in the middle childhood: links to peer and schools identification, and general self worth, Journal of developmental psychology, 37(2), https://doi.org//10.1111/bjdp.12268

Meeus, W. (2011). The study of adolescent identity formation 2000-2010.A review of longitudinal research. Journal of Research on Adolescence, 21, 75-94

Mohd, N., Yunus, M., Iskandar, I. (2010). Trust communication and healthy parent attachment: Journal of Social and Behavioral Sciences, 9(15), 29-1536.

Njoroge, M. \& Kirori, G. (2018) Blended Family Dynamics and Academic Performance Outcome of the Child in Kenya: Case of Kabete Sub-County in Kiambu County. Journal of Culture, Society and Development Vol.41, 18

Pace, U. \& Zappulla, C. (2011). Problem behaviors in adolescence: The opposite role played by insecure attachment and commitment strength. Journal of Child \& Family Studies, 20,854-862. doi: 10.1007/s10826-011-9453-4

Pietromonaco, P.R., \& Feldman Barrett, L. (2000). The internal working models concept: What do we really know about the self in relation to others? Review of General Psychology,4(2), 155-175. doi:10.1037/1089-2680.4.2.155

Ratner, K. (2014). The role of parenting attachment in identity development. UCF undergraduate research Journal 4(7), 1222-1514

Rehman, S., Butt, V. (2016).Parental attachment and peer bonds with identity development during adolescence: Journal of Sociology and Criminology, 4(2). https://doi.org/10,4172123754435.6 


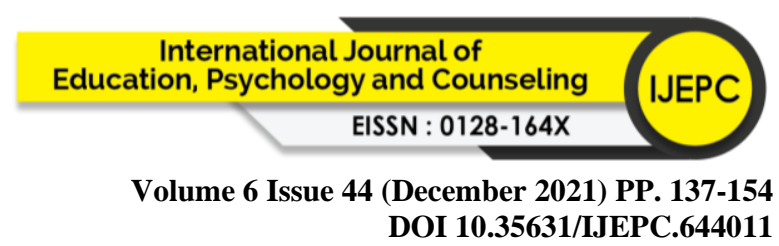

S, R., \& Butt F, Y. (2016). Parental Attachment and Peer Attachment Bonds with the Identity Development during Late Adolescence. Sociology and Criminology-Open Access, 04(02), 2-5. https://doi.org/10.4172/2375-4435.1000154

Samoulis, J., Layburn, K. \& Schiaffino, K.M. (2001).Identity development and attachment to parents in college students. Journal of Youth and Adolescence, 30, 373-384.

Samuolis, J., Layburn, K., AA Schiaffino, K. (2001). Identity development and attachment to parents in college. Journal of youth and adolescence, 30(3), 373-384. https://doi.org/10.1023/A:1010448313-516

Sandhu, D., Singh, B., Tung, S. \& Kundra, N. (2012).Adolescent identity formation, psychological well-being, and parental attitudes. Department of Psychology, Punjabi University, India.

Sesito, L. \&Sica, L. (2014). Identity formation of Italian emerging adults living with parents: A narrative study. The foundation for professionals in services for adolescents. Journal of Adolescence, 37(8), 1435-1447. Published by Elsevier

Shapiro, D. (2014). Stepparents and parenting stress: The roles of gender, marital quality, and views about gender roles. Family Process, 53(1), 97-108.doi:10.1111/famp.12062.

Smits, I., Soenens, B., Luyckx, K., Duriez, B., Berzonsky, M., \& Goossens, L. (2008). Perceived parenting dimensions and identity styles: Exploring the socialization of adolescents' processing of identity-relevant information. Journal of Adolescence, 31(2), 151-64.

Smits, I., Suenens, B., Luyckx, K., Duriez, B., Berzonsky, M., Goosens, L. (2008). Perceived parenting dimensions and identity styles; exploring the socialization of adolescents, processing of identity relevant information. Journal of adolescence, 31(2), 157-164, https://doi10.1016/j; adolescence.2007.08.007

Speer, R. B., Giles, H., \& Denes, A. (2013). Investigating stepparent-stepchild interactions: The role of communication accommodation. Journal of Family Communication, 13, 218-241. doi:10.1080/15267431.2013.768248

Vaughn BE, Waters TEA, Steele RD, et al. (2016) multiple domains of parental secure base support during childhood and adolescence contribute to adolescents' representations of attachment as a secure base script. Attachment \& Human Development. 18(4):317-336. doi: 10.1080/14616734.2016.1162180

Willis, B., \& Limb, G. E. (2016). The Impact of Stepfamily Adjustment on Adult Attachment: A Comparison of American Indians and Whites. Journal of indegenous Social Development, 5(2), 1-19

Wray-Lake, L., \& Syvertsen, A. K. (2011). The developmental roots of social responsibility in childhood and adolescence. New Directions for Child and Adolescent Development, $134,11-25$.

Zion, K.M., \& Dunifon, R. E. (2014). Complex living arrangements and child health: Examining family structure linkages with childrens health outcomes. Family relations, 63(3), 424-437. doi: 1111/fare.12071 